Article

\title{
Climate Change-Challenges and Response Options for the Port Sector
}

\author{
Sahar Azarkamand ${ }^{1, *}$, Alsnosy Balbaa ${ }^{2} \mathbb{}$, Christopher Wooldridge ${ }^{3}$ and Rosa Mari Darbra ${ }^{1, *}$ \\ 1 Resource Recovery and Environmental Management (R2EM), Department of Chemical Engineering, \\ Universitat Politècnica de Catalunya BarcelonaTech, Diagonal 647, 08028 Barcelona, Spain \\ 2 Arab Academy for Science, Technology and Maritime Transport, P.O. Box 1029, Alexandria 21913, Egypt; \\ african.affairs@aast.edu \\ 3 School of Earth and Ocean Sciences, Cardiff University, Main Building, Park Place, Cardiff CF10 3AT, UK; \\ wooldridge@cardiff.ac.uk \\ * Correspondence: sahar.azarkamand@upc.edu (S.A.); rm.darbra@upc.edu (R.M.D.); \\ Tel.: +34-934010811 (R.M.D.); Fax: +34-934017150 (S.A.)
}

Received: 6 June 2020; Accepted: 22 August 2020; Published: 26 August 2020

\begin{abstract}
Climate change is an established and growing priority environmental issue. This paper investigates the importance of climate change in ports through a research-based survey on data collected from participants at the Greenport Congress in Valencia in 2018. The data for this paper were obtained from the responses of 55 port professionals and environmental specialists that replied to a questionnaire survey during the Congress. Questionnaires were analyzed to identify the opinions and experience of delegates. A collaborative approach involving the free exchange of knowledge and experience between port professionals, industry practitioners and academia is the model most likely to deliver practicable options to the mutual advantage of operators, local communities, regulatory authorities and the environment. Based on the results of this survey, Climate Change occupies the 6th position among top 10 environmental port priorities and Carbon Footprint the 8th position. This reflects the importance of these two issues in the whole set of environmental priorities. Data collection has been identified as the main challenge ports encounter to implement a carbon management program. The need for a common port-sector Carbon Footprint scheme, which would benefit individual port authorities and the port-sector as a whole, was highlighted by the participants.
\end{abstract}

Keywords: climate change; ports; carbon footprint; $\mathrm{CO}_{2}$ emissions

\section{Introduction}

A port is a complex system that includes multiple elements many of which contribute to its environmental footprint. These can be segregated in maritime activities, in-port operations and hinterland transport. As transport activity has increased, so to have the intensity and range of impacts such as air pollution, noise pollution, $\mathrm{CO}_{2}$ emissions, and congestion [1].

In order to reduce these negative impacts, greening and sustainability issues have become more important in the maritime industry in recent years due to the legal requirements coming from international regulatory bodies such as international Maritime Organization (IMO) and the European Union (EU), and also due to external pressure by stakeholders in the industry. Moreover, the rising tide of political interest in combining growth with green is an explicit item on the agenda of many countries [2,3], pushing the ports to become more sustainable.

The port sector itself has been pro-active in delivering practicable options for dealing with the overall environmental challenge with initiatives such as EcoPorts (https://www.ecoports.com) and the International Associations of Ports and Harbors' World Ports Sustainability Program (https: 
//sustainableworldports.org) providing the sector with opportunities and options for networked collaboration. Climate change, with its wide range of manifestations and multidisciplinary components, continues to gain in significance and priority as recognized by those professional practitioners tasked with achieving the key objectives of compliance with legislation, environmental protection and sustainable development. It may reasonably be argued that the current pandemic of COVID-19 has further heightened the whole awareness of the quality of the environment in its broadest concept, given its significance to the quality of life of society and the challenges of keeping the key services of ports and international trade in operation.

\subsection{Green Port Concept}

The concept of the Green Port is based on the protection of the environment in all port infrastructure works and in the development of sustainable policies [4]. Therefore, the main aims of a Green Port should be to perform efficiently in economic terms, be ecologically sustainable and socially equal. These objectives could be achieved taking care of the exploitation of resources investment types, technology orientation and institutional changes [5]. A result of a survey in the current state of corporate sustainability in ports in Canada and the United States of America shows that the majority of ports perceive sustainability as important and have adopted a number of sustainability strategies and practices, such as sustainability awareness and training programs, sustainability reporting, and sustainability initiatives and standards [6].

In order to achieve a sustainable port, one of the steps that should be taken is to reduce the $\mathrm{CO}_{2}$ emissions in this area, as this is recognized as a significant component of climate change, the latter issue being one of the main topics at stake at the moment [7]. The next section represents some insights into initiatives being taken within the port sector.

\subsection{Climate Change}

Growing emissions of greenhouse gases (GHG) and their effects on climate are increasingly being recognized and reported as significant issues for the global community and mitigation plans to reduce the carbon footprint are becoming an important component of any business that claims to be sustainable. Climate Change due to $\mathrm{CO}_{2}$ emissions generated by transport has been considered a significant environmental threat [8-10]. Concerns about it were expressed already in 1979 when the first World Climate Conference was held [11]. By 1988, an Intergovernmental Panel on Climate Change was set up [12], followed in 1992 by the development of the United Nations Framework Convention on Climate Change (UNFCCC) [13]. In addition, in 1997 The Kyoto Protocol developed an action to limit greenhouse gas emissions [14].

The International Association of Ports and Harbors recognizes the significance of the increasing amounts of greenhouse gas emissions originated from port operations and activities and their role in climate change [15]. The shipping emissions generate approximately 1036 million tons of GHG emissions annually, and accounts for $2.4 \%$ of global carbon emissions [16]. The International Council on Clean Transportation predicted that greenhouse gas emissions from shipping activities will triple by 2050 [17]. Based on the result of a research from Winnes et al. [18] on greenhouse gas emissions from ships in ports, the emissions of $\mathrm{CO}_{2}$ are projected to increase by $40 \%$ to 2030 in a business as usual (BAU). For this reason, the problem of climate change has received increasing attention in the shipping sector [19]. The global community has recognized the fact that shipping is expected to become one of the fastest growing sectors in terms of greenhouse emissions [20]. To reduce these emissions, the Paris Agreement set the mitigation goal of limiting the global temperature increase up to $2{ }^{\circ} \mathrm{C}$ and ideally up to $1.5^{\circ} \mathrm{C}$ [21]. However, the greenhouse gas emissions have continued to rise [22]. The concentration of $\mathrm{CO}_{2}$ in the atmosphere has increased from approximately 277 parts per million (ppm) in 1750 [23] at the beginning of the industrial era, to $403 \mathrm{ppm}$ in 2016 [24]. The consequences of climate change (i.e., sea level rise, changes in weather or in the storm frequency) will impact in sea and inland ports. 
In this direction, IMO's recent decisions, such as the adoption of a strategy to reduce GHG emissions from shipping by $50 \%$ until 2050 (compared to 2008), made it necessary to take action to achieve this goal. In this direction, the European maritime community gathered during the Green Ship Technology Conference in Copenhagen (March 2019), proposed some solutions to reach these goals, such as the implementation of regulation, compliant fuels and expand or upgrade existing port infrastructure [25]. In a similar vein, at a recent conference of the International Maritime Transport and Logistics [26], organized by the Arab Academy of Science and held in Alexandria (March 2019), the delegates also confirmed the importance of research-led collaboration and technology in the whole debate on sustainable development of ports and in particular on climate change. The recommendations from Marlog 8 indicate awareness of the need for a networked and collaborative approach involving the full range of stakeholders linked by appropriate technology if projected objectives and targets related to major environmental issues such as climate change are to be met in a timely and cost-effective manner.

As another contribution to the topic of climate change, in 2020, PIANC (World Association for Waterborne Transport Infrastructure) Working Group Report No. 178 published a technical guidance document to help the owners, operators and users of waterborne transport infrastructure adapt to climate change [27].

Due to the importance of this topic, this paper investigates the awareness of climate change among port management through a research-based survey on data collected from participants to the Greenport Congress in Valencia in 2018.

\section{Materials and Methods}

The data of this paper was obtained from the responses of 55 port professionals and environmental specialists that replied to a questionnaire survey during the 2018 Valencia Greenport Congress which was held on the 17th and 18th October. The 55 workshop participants all completed the full questionnaire. Once the completed questionnaires were analyzed, conclusions were drawn by interpreting this information. A sample of the questionnaire can be found in Appendix A.

Initially, the questionnaire required to fill in the job description of the participant. Additionally, other personal data (name, email and organization) could be provided but it was not compulsory. Then, the survey was divided in four parts:

i. Identification of the top environmental priorities in the participant ports The participants were asked to fill in the five top environmental priorities in their organization in order of importance. The survey also asked if they were monitored and if performance indicators were selected for them.

ii. Questions on the relationship of the ports with climate issues A set of five questions with a Yes/No answer were included here, asking about topics such as the impact of climate change in their organizations or the preparation of risk assessment plans. Examples could be added for each question.

iii. Questions on Carbon Footprint Management A set of four questions with different type of answer were introduced in this section. The first one was Yes/No question, the second was a ranking one with five options and the last two were open questions.

iv. Analysis of the scheme of Carbon Footprint In this case, three Yes/No questions were asked to the participants in relation to issues such as the role in reducing the GHG emissions or the need of a common Carbon Footprint scheme.

As can be seen in Figure 1, these questionnaires were distributed among participants from all over the world. Among European countries (41 participants), most of the questionnaire responses were by Spanish participants (35\%), which is normal since the conference was held in Spain. After that, British, German and Finish participants were the most common ones ( $9 \%$ for each one). America was the second area with more representation (with nine participants from South America, North America and 
Canada). The African participants were Morocco, Ghana and Liberia. There was just one participant from Asia (Malaysia) and Australia, respectively.

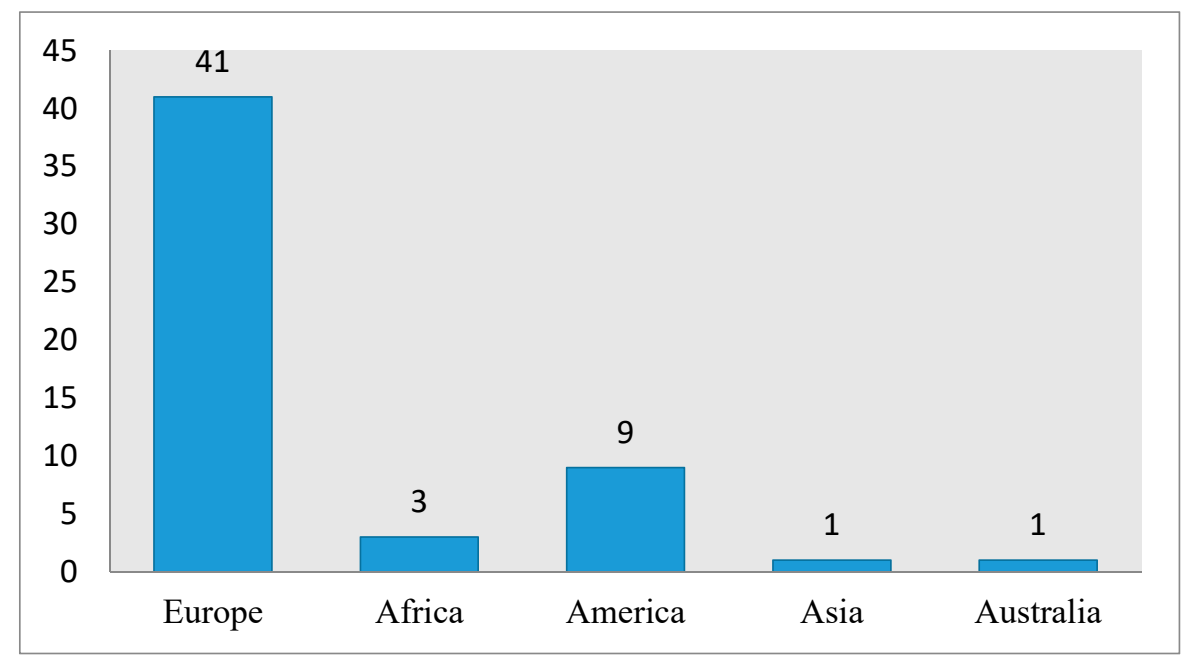

Figure 1. Geographical distribution of the participants (Number of participants in each continent).

The respondents who participated in the questionnaire represented professionals associated with the port sector and their job designations are shown in Figure 2. Most of the participants were environmental managers $(40 \%)$, followed by project managers $(17.5 \%)$, port top managers $(10 \%)$ and environmental experts $(10 \%)$. Around $70 \%$ of the answers belong to port authorities.

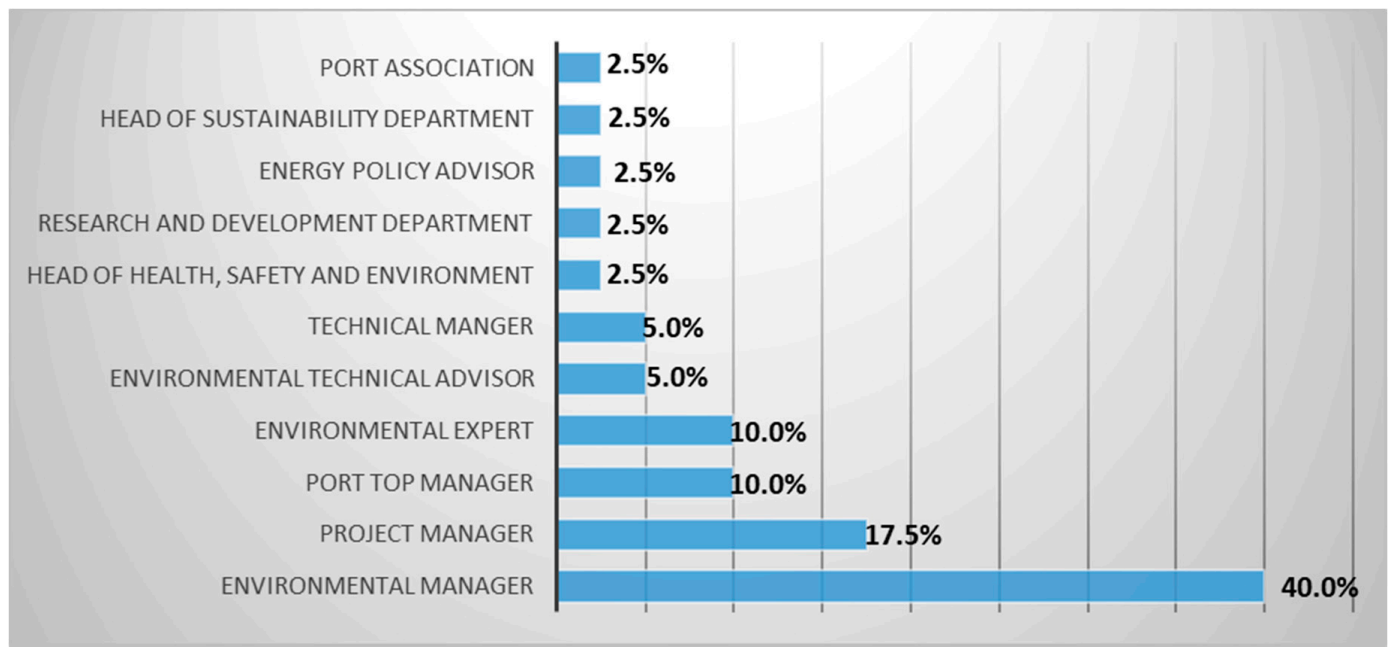

Figure 2. Participants' job position.

\section{Results}

The informal survey was deliberately taken during one of the sector's major, annual meetings in order to obtain a snap-shot of the opinions and priority issues of key operators. The group included members of ESPO's Sustainable Development Committee whose role it is to represent the environmental views of ports throughout the organization. The GreenPort Congress has an established reputation as a workshop event that deliberately sets out to bridge the gap between policy and practice, and its survey is seen as an opportunity to record some of the knowledge and experience that delegates bring to such events. The statistics per se are interpreted only as being indicative of the priorities, challenges and response options identified by influential professionals. The absolute percentages and rankings derived from the survey are not as significant or important as the trends that they identify and the 
fact they largely chime with other ESPO surveys and associated environmental reports. The opinions expressed offer an insight into the beliefs and judgments of port sector professionals which seem likely to be true though not necessarily based on proof. Nevertheless, they are an informed interpretation and worthy of scrutiny and study. Such questionnaires are useful in identifying common ground and highlighting differences.

The next subsections present the results of the survey for each of its parts. It is important to notice that no significant differences in the answers have been found when analyzing them in relation to different job's positions or countries.

\subsection{Environmental Aspects}

The Top 10 Environmental priorities are identified by delegates to the GreenPort Congress 2018. As can be seen in Table 1, 'Energy Consumption' is ranked as the most important environmental aspect- $-80 \%$ of participant ranked it as first priority, and this may be directly associated with the cost of electricity and fossil fuels, and the associated economic imperative.

Table 1. Top 10 Environmental priorities in Greenport Congress in Valencia and ESPO surveys in 2018 and 2019.

\begin{tabular}{cccc}
\hline & Greenport Congress Survey & ESPO Survey 2018 & ESPO Survey 2019 \\
\hline 1 & Energy consumption & Air quality & Air quality \\
2 & Air quality & Energy consumption & Energy consumption \\
3 & Waste & Noise & Climate Change \\
4 & Noise & community & Noise \\
5 & Water quality & Ship Waste & Relationship with Local \\
& Climate change & Land planning & Ship Waste \\
6 & Dredging operation & Climate change & Port Waste \\
7 & Land planning & Water quality & Land planning \\
8 & Carbon Footprint & & Dredging operation \\
8 & Relationship with Local & Dredging operation & Water quality \\
\hline 9 & community & Garbage/port waste & \\
\hline 10 & Transportation system in the & logistic chain &
\end{tabular}

'Air quality' was recognized as the second-highest environmental priority $(73 \%)$. This could be related with the health concern of port employees and citizens that live close to ports as mentioned in the study of Puig [28]. The third-ranked issue was 'Waste' (60\%) followed by 'Noise' (52\%). In most occasions, the main sources of noise are ships, although the industrial activities of other port tenants and operators may also be significant. 'Water quality' (42\%), 'Climate Change' (23\%) and 'Dredging Operations' (21\%) featured as significant issues. These issues occupy the 5th, 6th and 7th positions, respectively.

Ranked equal 8th position (alongside Land Planning) was 'Carbon Footprint' (13\%), itself closely linked with climate change. The fact that these two aspects are present in the 10 top environmental issues shows the increasing attention that ports are paying to climate change. 'The Relationship with Local community' and 'Transportation system in the logistic chain' (11\%) are occupying the last top-10 positions. The fact that the ranking includes 'Energy Consumption' (1st), 'Air quality' (2nd), 'Carbon Footprint' (8th) and 'Climate Change' itself (6th), demonstrates the extent to which the issue of Climate Change itself and its contributory issues are recognized by port sector professionals. 
A comparison of these results with ESPO Environmental Survey 2018 and 2019 [29,30] shows that there are some similarities between the results of the three surveys (Table 1). The relevant issues for this paper are illustrated in different grey colors in the three surveys. Based on the results of Greenport Congress, 'Energy Consumption' is the first, whereas in ESPO 2018 and 2019 survey it occupies the second position. However, 'Air quality' is the second issue for Greenport Congress and first for ESPO in both years. Therefore, the two main priorities are the same but in different position.

'Noise' occupies the same position in Greenport and ESPO 2019 (4th position) and the third position in ESPO 2018. 'Water quality' is in the 5th position in Greenport and in 8th in ESPO 2018 and 10th position in ESPO 2019. 'Climate Change' occupies a very similar position in both rankings-6th and 7th, respectively. However, in ESPO 2019, 'Climate Change' occupied the 3rd position and it shows the importance of this topic in recent years. 'The Relation with local community' occupies 9th position in Greenport whereas in ESPO 2018 is located in 4th position and in ESPO 2019 in 5th position. Overall, the top 10 issues for both surveys are quite coincident.

Table 2 shows the percentages of ports that monitor different Environmental Aspects. The results show that just over half of the ports monitor their Energy consumption, Air quality and Waste. In the case of Climate Change, which is the main topic of this research, only $13 \%$ of ports monitor it directly.

Table 2. Percentage of ports that monitor different Environmental Aspects.

\begin{tabular}{cc}
\hline Issue & Percentage (\%) \\
\hline Energy consumption & 54 \\
Air quality & 52 \\
Waste & 49 \\
Noise & 38 \\
Water quality & 32 \\
Climate change & 13 \\
Dredging operation & 14 \\
Land planning & 4 \\
Carbon Footprint & 7 \\
Relationship with Local community & 2 \\
\hline
\end{tabular}

Table 3 shows the percentage of monitoring issues that have identified associated Environmental Performance Indicators. Just under $50 \%$ of the ports are using Environmental Performance Indicators in the case of Energy Consumption. For the issues of Air quality, Waste and Noise, around 30\% of the ports are using performance indicators in efforts to control them. In the case of Climate Change only $13 \%$ of ports have performance indicators to measure this aspect.

Table 3. The percentage of monitoring issues that have associated Environmental Performance Indicators in ports.

\begin{tabular}{cc}
\hline Issue & Percentage (\%) \\
\hline Energy consumption & 49 \\
Air quality & 38 \\
Waste & 34 \\
Noise & 27 \\
Water quality & 20 \\
Climate change & 13 \\
Dredging operation & 11 \\
Land planning & 4 \\
Carbon Footprint & 4 \\
Local community & 0 \\
\hline
\end{tabular}




\subsection{Climate Change}

This part of the paper investigates the awareness of port organizations about climate change and their efforts to control it. Based on the results of this survey, $81 \%$ of ports organizations believe that the influences of climate change, such as sea level rise and increased storminess, have impacts on their organizations. This shows that they are aware of the significance of this issue. The port sector's own Self-Diagnosis Methodology, (SDM, www.ecoports.com) recently included questions related to climate change concerning operational challenges, strengthening of infrastructures and adaptation to change as part of new projects. Concerning the existence of a climate change Risk Assessment plan, $57 \%$ of the participants declared to have a plan to face this situation. This type of plan is normally included in a wider risk management scheme of the port. Its aim is to determine the future climate hazards and how to act to reduce them [31]. In addition, $81 \%$ of organizations collaborate with other, third-party organizations on the issue of climate change. This shows that ports are already taking in to account the port community and other stakeholders to face climate change.

One of the main problems that ports encounter to deal with climate change is collecting data and having sufficient information. Based on the results of this research, only $47 \%$ of organizations are collecting data on climate change. Moreover, only $24 \%$ of organizations are aware of the future released of PIANC WG 178 guidelines that will help port operators to face Climate Change.

\subsection{Management of Carbon Footprint}

In this part, different aspects will be commented such as the reporting on carbon footprint, main drivers to implement carbon management, key stakeholders for development of carbon management program and the major challenges and problems for developing and implementing a carbon management program.

The results show that $62 \%$ of the organizations report their carbon emissions. However, the method used has not been specified. A study by Azarkamand et al. [32] shows that, in recent years, many ports have started to calculate and report their carbon footprint. This is a positive sign in terms of the "greening" of ports. However, each port uses its own method and there is not any unified method to calculate carbon footprint in ports. In addition, in most of the cases, all the direct and indirect emission sources mentioned in the standard guidelines are not calculated, and emissions from waste treatment operations and employees' commuting are excluded from the total calculation of $\mathrm{CO}_{2}$. This makes the current calculations in some occasions unrealistic.

Table 4 presents the main drivers to implement carbon management which categorize in five priorities. The first driver is the 'Leadership role'; this means that the main reason for ports to manage carbon is being the leadership in these types of practices. After that, 'Compliance with emerging regulations' is the driver with the most impact which is self-evident as compliance with legislation is non-negotiable. The next driver is 'Potential to influence practice and regulation through innovation and investment'. Port policy for the sector is generally that pro-active initiatives that help representative organizations to retain influence in future legal requirements. 'Opportunity to reduce and offset emissions from infrastructure development' together with 'Stakeholder pressure to reduce environmental impacts' are also recognized as important drivers to implement carbon management.

Table 4. The main drivers to implement Carbon Management.

\begin{tabular}{cc}
\hline Drivers & Priority \\
\hline Leadership role in Carbon management practices & 1 \\
Compliance with emerging regulations & 2 \\
Potential to influence practice and regulation through innovation and investment & 3 \\
Opportunity to reduce and offset emissions from infrastructure development & 4 \\
Stakeholder pressure to reduce environmental impacts & 5 \\
\hline
\end{tabular}


Table 5 shows the key stakeholders for the development of carbon management program in a port. Based on the results of the survey, 'Port operators' and 'ship owners' are those which have an important role for the development of carbon management program. Outside the port, the 'Government' is the main driver to implement carbon management plans.

Table 5. The key stakeholders for the development of a carbon management program in a port.

\begin{tabular}{lccc}
\hline The Key Stakeholders & Number & Percentage (\%) \\
\hline 1 & Port Operators & 18 & $25 \%$ \\
2 & Ship Owners & 10 & $15 \%$ \\
3 & Government & 7 & $9 \%$ \\
4 & Senior manager & 6 & $8 \%$ \\
5 & Municipality & 5 & $6 \%$ \\
5 & Port Authorities & 5 & $6 \%$ \\
6 & Environmental & 4 & $4 \%$ \\
7 & department & 3 & $3 \%$ \\
8 & Customers & 17 & $24 \%$ \\
\hline
\end{tabular}

'Municipality' and 'Port authorities' equally occupy the fifth position. It may be considered surprising that the 'Environmental department' which many would assume to have a key role for development of carbon management program is only ranked in the sixth position just above 'Customers'.

The major challenges and problems for developing and implementing a carbon management program are illustrated in Table 6. The most important challenge is 'Data collection'; gathering accurate data for calculating carbon footprint and GHG is a critical issue. This is linked directly with the second problem, 'Measuring and calculating data'. The third position belongs to two aspects: 'Coordination among stakeholders' and 'Legislation', with an equal percentage. These are two very important topics within a port. 'External costs', 'Limited carbon management program to local footprint' and 'Setting boundaries for measuring shipping emission', occupy the fourth position with equal importance. Therefore, solving these problems could help port organizations to work on a climate issue in a more suitable way.

Table 6. The major challenges and problems of developing and implementing a carbon management program.

\begin{tabular}{lccc}
\hline & Major Challenges and Problems & Number & Percentage (\%) \\
\hline 1 & Data collection & 18 & $26 \%$ \\
2 & Measuring and calculating Data & 14 & $20 \%$ \\
3 & Coordination among stakeholders & 7 & $10 \%$ \\
3 & Legislation & 7 & $10 \%$ \\
4 & External costs & 6 & $9 \%$ \\
4 & Limited to local footprint & 6 & $9 \%$ \\
4 & Set boundaries for measuring & 6 & $9 \%$ \\
5 & shipping emission & 5 & $7 \%$ \\
\hline
\end{tabular}

\subsection{Carbon Footprint Scheme}

The European Union and its Member States prefer a global approach on the issue of Carbon Footprint. This is supported by the International Maritime Organization (IMO) and the United Nations Framework Convention on Climate Change (UNFCCC). This approach is also in line to ensure that the sector can contribute in a fair way to the objective of the Paris agreement, this is, to limit the average increase of the temperatures to $1.5^{\circ} \mathrm{C}$. In addition, in 2008, the World Ports Climate Initiative (WPCI) developed by the International Association of Ports and Harbors (IAPH) to assist ports in controlling 
climate change [15]. In 2010, WPCI developed guidelines to serve as an introduction to "Carbon Footprinting" and as a resource guide for ports wanting to develop or improve the inventories of their GHG emissions [33].

Moreover, the 72nd session of the Marine Environment Protection Committee (MEPC 72) was held in April 2017 at IMO's headquarters in London. The outcome of this session was adoption of the initial IMO strategy on reduction of GHG emissions from ships by at least $50 \%$ by 2050 compared to 2008 and decline carbon intensity of international shipping via reduction of $\mathrm{CO}_{2}$ emissions per transport work, by at least $40 \%$ by 2030 , pursuing efforts towards $70 \%$ by 2050 , compared to 2008 [34].

Another initiative, the World Ports Sustainability Program (WPSP), demonstrated global leadership of ports in contributing to the Sustainable Development Goals of the United Nations, along five themes. The second of these is related to climate change and energy [35]. More recently, in 2020, PIANC Working Group 178 published a technical guidance document to help the owners, operators and users of waterborne transport infrastructure adapt to climate change [27].

In order to understand the number of ports that are aware about their role in greenhouse gas emission control and the importance of it, this survey introduced a question on this. Almost $94 \%$ of organizations are aware about their role in reducing GHG. Moreover, $89 \%$ of the ports consider that a common port-sector carbon footprint scheme would benefit individual port authorities and the port-sector as a whole. Nowadays, there exist different systems and each port is using its own. Therefore, comparisons between the different values obtained are complicated. In addition, $86 \%$ of respondent ports consider that GHG emissions from shipping generated in a port area should be included as third-party emissions in the carbon footprint of the port.

\section{Discussion}

In the highly competitive world of the port sector and shipping industries, it may reasonably be suggested that the one issue on which collaboration may be to mutual advantage is that of Environment and, in particular, Climate Change. Noticeably, since 2006, published articles related to green ports and maritime logistics have become an important research area and a critical branch of sustainable supply chain management research [36]. The free exchange of knowledge and experience is likely to assist all players in achieving compliance, cost and risk reduction, and overall environmental protection. Why re-invent the wheel when good practice options are available? Why not share costs in developing new, innovative solutions? To discuss any one issue in isolation detracts from the reality that climate change requires a comprehensive and integrated approach to the cross-boundary and multi-component issues that represent the impacts of the activities, products and services associated with port and shipping operations.

For this reason, conferences such as Marlog 8 or GreenPorts Valencia are suitable places to gather information and exchange knowledge on topics such as Climate Change. This issue is an established and growing priority Environmental issue recognized by port professionals and the sector itself, as witnessed by the ESPO Survey of 2018, 2019 and the results of the in-conference workshop of GreenPorts Valencia.

The data for this paper were derived from the responses of 55 port and maritime professionals from a range of related backgrounds and responsibilities. Survey questionnaires were completed during an interactive session at the Greenport Congress, Valencia which was held the 17th and 18th October, 2018.

Energy consumption is confirmed as a priority issue which along with $\mathrm{CO}_{2}$ and GHG gases emissions flags awareness of the significance to climate change. This latter issue occupies a very similar position in Greenport and ESPO 2018 survey ranking 6th and 7th, respectively. However, in ESPO 2019, climate change occupied the third position among the top 10 environmental priorities. Controlling energy consumption indirectly could reduce $\mathrm{CO}_{2}$ emission and GHG gases. Carbon Footprint is also in the top 10 priorities. This reflects the importance of these issues in the whole program of environmental priorities for both individual ports and the sector itself. 
The results of this survey show that most of the ports representatives believe that climate change has an impact on their organizations. Additionally, it indicates that most of them are aware of the importance of this matter but few of them monitor climate change or have associated Environmental performance indicators to control it. On this basis, it may be suggested that ports actively make more efforts to monitor the impact on climate change of their significant aspects based on appropriate EPIs.

Around half of the representatives reported that there exist a Climate Risk Assessment plan and most of them have collaboration with other third-party organizations on the issue of climate change. Less than half of the ports are collecting data on climate change. However, more than a half of participants report their carbon emissions. The problem is the way they do so and how each institution is using its own method.

Data collection, measuring and calculating data and coordination among stakeholders are the most important challenges in implementing a carbon management program.

In the case of the role of ports in reducing Greenhouse Gas Emissions, results show that most of the participants are aware about their role in reducing GHG. Most of the respondents consider that GHG emissions from shipping generated in port area should be included as third-party emission in carbon footprint of the port. In addition, most of them consider that a common, port-sector carbon footprint scheme would benefit individual port authorities and the port-sector as a whole. Therefore, development of a practicable tool with a standardized method for the calculation of Carbon Footprint would be helpful and necessary in this case. This method should be user-friendly and practicable. As the emissions from ships have not been taken in to account until now, including these emissions in the new method would make the Carbon Footprint calculation in ports more representative.

Therefore, as the ports are home to many diverse sources and modes of transportation that directly and indirectly contribute to GHG emissions, the implementation actions to reduce the impacts of these sources on the environment are needed. Based on the research from Aregall et al., the technology improvements, infrastructure development and monitoring programs are the best measures to improve the environmental performance in ports [37].

In addition, as mentioned before, the shipping emissions account for $2.4 \%$ of global carbon emissions. Therefore, some solutions are needed to eliminate shipping emissions. Based on the research from Zis, cold ironing, which is a process of providing shore power to cover the energy demands of ships calling at ports, can eliminate the emissions of auxiliary engines at berth [38].

Another study investigated different kinds of measures for emission reductions for diverse types of vessels and parts of the port area. A case study of the ship traffic to the Port of Gothenburg is performed. Projections of ship emissions in the port area for 2030 were made, and three scenarios, 'Alternative fuel', 'Ship design' and 'Operation', were analyzed. These scenarios were related to a business as usual development. GHG emissions from ships in the port are projected to increase by $40 \%$ to 2030 in a business as usual (BAU) scenario. The highest reductions were seen in the 'Operation' scenario where GHG emissions were $10 \%$ lower than the BAU level [18].

As a conclusion, the results of our survey show that ports are paying attention to climate change and carbon management in ports. The fact that ports become aware of the importance of Climate Change is reflected in their daily activities such as taking steps to strengthen the resilience of their existing infrastructure in order to adapt to climate change or considering climate change adaptation as part of new infrastructure development projects.

However, this is just a first step, and not all the ports have either data or methods to calculate carbon footprint. Therefore, more research should be done to help with calculating and controlling GHG emissions in the maritime industry.

These views confirm the notion that only an integrated, collaborative and research-based approach will deliver a comprehensive pathway within which specific issues, such as Climate Change, may be effectively managed in a practicable and pragmatic manner. 
Author Contributions: Conceptualization, C.W.; methodology, C.W.; validation, C.W. and R.M.D.; formal analysis, S.A. and R.M.D.; investigation, S.A. and C.W.; resources, R.M.D.; data curation, A.B.; writing-S.A. and R.M.D.; writing-review and editing, C.W. and A.B.; supervision, R.M.D.; All authors have read and agreed to the published version of the manuscript.

Funding: This research received no external funding.

Acknowledgments: The authors would like to acknowledge the survey participants for their contribution to the Greenport Conference Workshop.

Conflicts of Interest: The authors declare no conflict of interest.

\section{Appendix A. Sample Questionnaire}

Greenport Congress, Valencia 2018-Session 3-YOU CAN'T MANAGE WHAT YOU CAN’T MEASURE

Delegate Input

Delegate's name (Optional)

Email (Optional)

Organization (Optional)

Job description

NOTE: All data and information received will be treated in strict confidence and reported anonymously. Your views and recommendations will be incorporated into the Summary Report to be produced as a conference deliverable. It would be helpful in the analysis to be aware of your job description, and should you be interested in follow-up research opportunities it would be most helpful to be able to contact you. Thank you for your cooperation.

1. What are the Top-5 priority Environmental priority issues/aspects in your Organization *?

\begin{tabular}{|c|c|c|c|}
\hline Priority & Issue/Aspect & Monitored? YES, or NO & $\begin{array}{c}\text { Environmental Performance Indicator(s) } \\
\text { Selected? YES, or NO }\end{array}$ \\
\hline 1 & & & \\
\hline 2 & & & \\
\hline 3 & & & \\
\hline 4 & & & \\
\hline 5 & & & \\
\hline
\end{tabular}

* In this Survey, the word organization refers to any of the following: Port Authority, Terminal Operator, Shipping Company, Maritime Logistics Support, or other port-related entity.

2. Climate Change

\begin{tabular}{|c|c|c|c|}
\hline & Issue & Yes, or No & Details/Example \\
\hline (a) & $\begin{array}{l}\text { Is climate change impacting your organization *? (In terms of } \\
\text { operations, functions, construction projects etc) }\end{array}$ & & \\
\hline (b) & $\begin{array}{l}\text { Has your organization * prepared risk assessment specifically related } \\
\text { to climate change? (Detailed? Basic? Contingency? EIA?). }\end{array}$ & & \\
\hline (c) & $\begin{array}{c}\text { Is your organization * collaborating with other, third-party, } \\
\text { organizations on the issue of climate change? }\end{array}$ & & \\
\hline (d) & Is your organization * collecting data/information on climate change? & & \\
\hline (e) & $\begin{array}{c}\text { Is your organization * using, or is it aware of, PIANC WG } 178 \\
\text { Guidelines/Tool kit. }\end{array}$ & & \\
\hline
\end{tabular}

\section{Carbon Footprint Management}

(a) Does your organization report on Carbon emissions? YES, or NO (please circle) 
(b) What are the main drivers to implement Carbon Management?-please prioritize in the following table where $1=$ highest priority, $5=$ lowest

\begin{tabular}{cc}
\hline Drivers & Priority (Allocate 1-5) \\
\hline Compliance with emerging regulations & \\
Stakeholder pressure to reduce environmental impacts & \\
Leadership role in Carbon management practices & \\
Potential to influence practice and regulation through innovation and investment & \\
Opportunity to reduce and offset emissions from infrastructure development & \\
\hline
\end{tabular}

(c) Which stakeholders are the key players for development of a Carbon management program in your organization?

(d) In your opinion, what are the major challenges and problems of developing and implementing a Carbon management program? What are your recommended best options?

\section{Carbon Footprint Scheme}

(a) Do you consider that ports have a role to play in reducing Greenhouse Gas Emissions (GHG) from shipping? YES, or NO (Please circle)

(b) Do you consider GHG emissions from shipping generated in the port area should be included as third-party emissions in Carbon Footprint of the port? YES, or NO (Please circle).

(c) Do you consider that a common, port-sector Carbon Footprint Scheme would benefit individual Port Authorities and the Port-Sector as a whole? YES, or NO (Please circle).

On behalf of GreenPort Congress, thank you for your cooperation in contributing your experience, opinions and recommendations. The results will be analyzed by independent academics with initial results being reported direct to the GreenPort Congress on Day 2, and a more detailed report communicated by GreenPort website and Journal in due course. As stated at beginning of this input template, full confidentiality of data origin will be observed.

\section{References}

1. Chiu, R.-H.; Lin, L.-H.; Ting, S.-C. Evaluation of Green Port Factors and Performance: A Fuzzy AHP Analysis. Math. Probl. Eng. 2014, 2014, 1-12. [CrossRef]

2. Asgari, N.; Hassani, A.; Jones, D.; Nguye, H.H. Sustainability ranking of the UK major ports: Methodology and case study. Transp. Res. Part E Logist. Transp. Rev. 2015, 78, 19-39. [CrossRef]

3. González-Laxe, F.; Bermúdez, F.M.; Palmero, F.M.; Novo-Corti, I. Sustainability and the Spanish port system. Analysis of the relationship between economic and environmental indicators. Mar. Pollut. Bull. 2016, 113, 232-239. [CrossRef] [PubMed]

4. Anastasopoulos, D.; Kolios, S.; Stylios, C. How Will Greek Ports Become Green Ports? Geo-Eco-Marina 2011, 17, 73-80. Available online: https://geoecomar.ro/website/publicatii/Nr.17-4362011/09_anastapoulos_BT.pdf (accessed on 20 August 2019).

5. UNCTAD. Sustainable Development for Ports. Report UNCTAD (SDD/Port); UNCTAD: Geneva, Switzerland, 1993; Volume 1, p. 27.

6. Ashrafi, M.R.; Acciaro, M.; Walker, T.R.; Magnan, G.M.; Adams, M.; Magnan, G.M. Corporate sustainability in Canadian and US maritime ports. J. Clean. Prod. 2019, 220, 386-397. [CrossRef]

7. Schipper, C.; Vreugdenhil, H.; De Jong, M. A sustainability assessment of ports and port-city plans: Comparing ambitions with achievements. Transp. Res. Part. D Transp. Environ. 2017, 57, 84-111. [CrossRef] 
8. Åkerman, J.; Höjer, M. How much transport can the climate stand?-Sweden on a sustainable path in 2050. Energy Policy 2006, 34, 1944-1957. [CrossRef]

9. Koroneos, C.J.; Nanaki, E. Environmental assessment of the Greek transport sector. Energy Policy 2007, 35, 5422-5432. [CrossRef]

10. Zervas, E.; Lazarou, C. Influence of European passenger cars weight to exhaust CO2 emissions. Energy Policy 2008, 36, 248-257. [CrossRef]

11. Sprinz, D.; Luterbacher, U. International Relations and Global Climate Change. Potsdam Institute for Climate Impact Research Report No. 21 1996. p. 105. Available online: https://www.pik-potsdam.de/research/public ations/pikreports/.files/pr21.pdf (accessed on 18 January 2019).

12. IPCC (Intergovernmental Panel on Climate Change). IPCC Factsheet: Timeline-Highlights of IPCC History. 2015. Available online: https://www.ipcc.ch/site/assets/uploads/2018/04/FS_timeline.pdf (accessed on 7 July 2019).

13. United Nations. United Nations Framework Convention on Climate Change. 1992. Available online: https://unfccc.int/resource/docs/convkp/conveng.pdf (accessed on 12 December 2018).

14. United Nations Framework Convention on Climate Change. Kyoto Protocol to the United Nations Framework Kyoto Protocol to the United Nations Framework. Review of European Community and International Environmental Law. 1998. Available online: https://unfccc.int/resource/docs/convkp/kpeng.pdf. (accessed on 26 December 2018).

15. IAPH (International Association of Ports and Harbors). IAPH Tool Box for Port Clean Air Programs. 2010. Available online: http://iaphtoolbox.wpci.nl/DRAFTIAPHTOOLBOXdea.pdf (accessed on 16 March 2019).

16. IMO (International Maritime Organization). Third IMO Greenhouse Gas Study 2014. 2014. Available online: http://www.imo.org/en/OurWork/Environment/PollutionPrevention/AirPollution/Documents/Thir dGreenhouseGasStudy/GHG3ExecutiveSummaryandReport.pdf (accessed on 16 March 2019).

17. Olmer, N.; Comer, B.; Roy, B.; Mao, X.; Rutherford, D. Greenhouse Gas Emissions from Global Shipping. 2013-2015; International Council on Clean Transport: Washington, DC, USA, 2017; p. 27. Available online: https://theicct.org/sites/default/files/publications/Global-468shipping-GHG-emissions-2013-2015_I CCT-Report_17102017_vF.pdf (accessed on 10 April 2019).

18. Winnes, H.; Styhre, L.; Fridell, E. Reducing GHG emissions from ships in port areas. Res. Transp. Bus. Manag. 2015, 17, 73-82. [CrossRef]

19. Gibbs, D.; Rigot-Müller, P.; Mangan, J.; Lalwani, C. The role of sea ports in end-to-end maritime transport chain emissions. Energy Policy 2014, 64, 337-348. [CrossRef]

20. Gilbert, P.; Manchester, T.; Starkey, R.; Manchester, T. Shipping and Climate Change: Scope for Unilateral Action. The University of Manchester. 2010, p. 83. Available online: http://shippingefficiency.org/sites/ship pingefficiency.org/files/Tyndall.pdf475 (accessed on 5 March 2019).

21. United Nations. Paris Agreement. 2015. Available online: https://unfccc.int/sites/default/files/english_paris _agreement.pdf. (accessed on 26 December 2018).

22. Le Quéré, C.; Andrew, R.M.; Canadell, J.G.; Sitch, S.; Korsbakken, J.I.; Peters, G.P.; Manning, A.C.; Boden, T.A.; Tans, P.P.; Houghton, R.A.; et al. Global Carbon Budget 2016. Earth Syst. Sci. Data 2016, 8, 605-649. [CrossRef]

23. Joos, F.; Spahni, R. Rates of change in natural and anthropogenic radiative forcing over the past 20,000 years. Proc. Natl. Acad. Sci. USA 2008, 105, 1425-1430. [CrossRef] [PubMed]

24. NOAA and ESRL (National Oceanic \& Atmospheric Administration and Earth System Research Laboratory). Trends in Atmospheric Carbon Dioxide. 2019. Available online: https://www.esrl.noaa.gov/gmd/ccgg/trends/ full.html (accessed on 8 April 2019).

25. BPO. Collaboration-Maritime Industry's Path to 2030. 2019. Available online: http://www.bpoports.com/c ollaboration-maritime-industry $\backslash \mathrm{T} 1 \backslash$ textquoterights-path-to-2030.html (accessed on 6 April 2019).

26. Marlog (The International Maritime Transport and Logistics Conference "Marlog 8"). Alexandria, Egypt, 2019. Available online: https://marlog.aast.edu/en/home (accessed on 2 May 2019).

27. PIANC (The World Association for Waterborne Transport Infrastructure). Climate Change Adaptation Planning for Ports and Inland Waterways, EnviCom WG Report $n^{\circ} 178.2020 ;$ p. 190. ISBN 978-2-87223-001-3. Available online: https://www.pianc.org/uploads/publications/reports/WG-178.pdf (accessed on 10 January 2020).

28. Puig Duran, M. Methodology for the selection and implementation of environmental aspects and performance indicators in ports. Ph.D. Thesis, Universitat Politècnica de Cataluña, Barcelona, Catalonia, Spain, 2016. 
29. ESPO (European Sea PortsOrganization). Environmental Report 2018 EcoPortsinsights 2018. 2018; pp. 1-18. Available online: https://www.espo.be/media/ESPOEnvironmentalReport2018.pdf (accessed on 26 December 2018).

30. ESPO (European Sea PortsOrganisation). Environmnetal Report 2019 EcoPortsSights 2019; ESPO: Abertillery, UK, 2019; pp. 1-23. Available online: https://www.espo.be/media/EnvironmentalReport-2019499FINAL.pdf (accessed on 21 October 2019).

31. Scott, H.; McEvoy, D.; Chhetri, P.; Basic, F.; Mullett, J. Climate change adaptation guidelines for ports. National Climate Change Adaptation Research Facility, Gold Coast. 2013; pp. 1-28. ISBN 978-1-921609-83-1. Available online: https://www.researchgate.net/publication/274570189_Climate_change_adaptation_guideli nes_for_503ports (accessed on 12 December 2019).

32. Azarkamand, S.; Wooldridge, C.; Darbra, R.M. Review of Initiatives and Methodologies to Reduce $\mathrm{CO}_{2}$ Emissions and Climate Change Effects in Ports. Int. J. Environ. Res. Public Health 2020, 17, 3858. [CrossRef] [PubMed]

33. WPCI (World Ports Climate Initiative). Carbon Footprinting for Ports, Guidance Document. 2010; pp. 1-83. Available online: http://wpci.iaphworldports.org/data/docs/carbonfootprinting/PV_DRAFT_WPCI_Carbon_ Footprinting_510Guidance_Doc-June-30-2010_scg.pdf (accessed on 15 November 2018).

34. IMO (International Maritime Organization). Initial IMO Strategy on Reduction of GHG Emissions from Ships. Resolution MEPC. 304 (72), 2018. Available online: http://www.imo.org/en/OurWork/Documents/Res olution\%20MEPC.304\%2872\%29\%20on\%20Initial\%20IMO\%20Strategy\%20on\%20reduction\%20of\%20G HG\%20emissions\%20from\%20ships.pdf (accessed on 5 April 2019).

35. WPSP (World Ports Sustainability Program). World Ports Sustainability Program. 2018; pp. 1-4. Available online: https://sustainableworldports.org/wp-content/uploads/wpsp-declaration.pdf (accessed on 5 April 2019).

36. Davarzani, H.; Fahimnia, B.; Bell, M.; Sarkis, J. Greening ports and maritime logistics: A review. Transp. Res. Part D Transp. Environ. 2016, 48, 473-487. [CrossRef]

37. Aregall, M.G.; Bergqvist, R.; Monios, J. A global review of the hinterland dimension of green port strategies. Transp. Res. Part D Transp. Environ. 2018, 59, 23-34. [CrossRef]

38. Zis, T.P. Prospects of cold ironing as an emissions reduction option. Transp. Res. Part. A Policy Pr. 2019, 119, 82-95. [CrossRef] 